\title{
Mainstream Media and the F-Word: Documentary Coherence and the Exclusion of a Feminist Narrative in The Fifth Estate Coverage of the Ashley Smith Case
}

\author{
Charissa Crépault and Jennifer M. Kilty
}

\begin{abstract}
This article offers a narrative analysis of the two CBC Fifth Estate investigative documentaries about Ashley Smith ("Behind the Wall," 2010; "Out of Control," 2010) and juxtaposes the documentary narratives against claims made by feminist criminologists with respect to women's corrections. Examining the coherent 'through narrative' that is constructed in each documentary, we claim that The Fifth Estate uses dominant medicalized conceptualizations of mental illness and mental health treatment to frame the Smith case, leaving questions about the gendered nature of her criminalization, imprisonment and mistreatment unasked. Considering the sociopolitical context of neoliberal and post-feminist individualism, we argue that The Fifth Estate presents the case in a way that maintains the status quo and may resonate with their national audience, but which also reinforces the pathologization of women prisoners and upholds gendered stereotypes.
\end{abstract}

Keywords: feminist criminology, Ashley Smith, narrative, investigative documentary, mental illness, women's corrections

\section{Résumé}

Cet article comprend l'analyse de deux documentaires d'enquête portant sur Ashley Smith ("Behind the Wall," 2010; et “Out of Control," 2010) réalisés par l'émission de la CBC, The Fifth Estate. L'article juxtapose l'élaboration des documentaires aux prétentions de criminologues féministes à l'égard des établissements correctionnels pour femmes. Après avoir examiné le fil narratif de ces deux documentaires, nous posons que The Fifth Estate a eu recours à des conceptualisations dominantes de la maladie mentale et du traitement en santé mentale pour mettre en scène l'affaire Ashley Smith et a laissé de côté le caractère genré de sa criminalisation, de son emprisonnement et des mauvais traitements quelle a subis. Compte tenu du contexte socio-politique de l'individualisme néolibéral et post-féministe, nous posons que The Fifth Estate présente l'affaire Ashley Smith de façon à préserver le statu quo et à susciter davantage l'intérêt de son public, ce qui a pour conséquence de renforcer la pathologisation des femmes détenues et les stéréotypes genrés.

Mots clés : criminologie féministe, Ashley Smith, fil narratif, documentaire d'enquête, santé mentale, centres correctionels pour femmes

Canadian Journal of Law and Society / Revue Canadienne Droit et Société, 2017,

Volume 32, no. 2, pp. 269-290. doi:10.1017/cls.2017.12 


\section{Introduction}

Ashley Smith's mistreatment while incarcerated and her eventual death inside a segregation cell at the Grand Valley Institution for Women in Kitchener, Ontario demonstrate a number of the injustices that continue to plague Canadian women's prisons. For decades several feminist criminologists have problematized the use of solitary confinement as a standard response to women who self-injure or who are deemed mentally ill (Dell, Fillmore, and Kilty 2009, 297; Kilty 2006, 167; Martel 2006, 592). Smith engaged in chronic self-injurious behaviour and, as a result, was illegally held in permanent segregation throughout her time in federal custody. In order to contravene the correctional policy that limits the length of time a prisoner may be held in isolation, the Correctional Service of Canada (CSC) transferred Smith seventeen times in eleven months, restarting the "segregation clock" each time she was transferred. While incarcerated, Smith was subject not only to extra-punitive forms of seclusion and restraint, but also to multiple instances of tasering, involuntary injections of psychotropic medications, gassing, and pepper spray. On October 19, 2007, Smith tied a ligature around her neck and laid face down on the floor between her bed and the wall. Under orders from management not to intervene until Smith had passed out from ligature use, correctional staff failed to respond to the medical emergency, resulting in her death.

In the months and years that followed, the case received a great deal of media attention, including the production of two hour-long investigative documentaries released by the $C B C$ 's The Fifth Estate that show video evidence of Smith's mistreatment and feature interviews with key figures and witnesses. Together, these two episodes construct a particular narrative about Smith's incarceration and death. The first episode, "Out of Control" (January 2010), describes Smith's life prior to incarceration, her time spent inside both youth and adult correctional facilities and the incidents surrounding her death, advancing the argument that Smith's life was "taken from her." The second episode, "Behind the Wall" (November 2010), builds on the conclusions in "Out of Control" and uses the case as a springboard to engage in a broader discussion of how prisoners with mental illness are (mis) treated in Canadian prisons.

In a behind-the-scenes episode entitled Secrets of the Fifth Estate (2015), a senior producer identified "the desire to expose injustice [and] expose abuse of power" (Harvey Cashore) as the driving force behind the show. The Fifth Estate's commitment to exposing injustice is certainly evident in its coverage of the Smith case, which expressly condemns her (mis)treatment and identifies some of the very real problems with mental health care in the prison system (e.g., lack of staff training, the use of physical and chemical restraints, and inadequate resources). Contending with CSC's efforts to keep video evidence from the public eye, The Fifth Estate exposed the mistreatment of mentally ill prisoners and the lack of accountability permeating Canadian prisons, earning them the Governor General's Michener Award ${ }^{1}$ in 2010. Recognizing The Fifth Estate's laudable work to bring

1 The Michener Award celebrates journalism deemed unbiased, professional, impactful, and beneficial to the public. 
attention to abuses and injustices in the prison system, we nonetheless think that it is useful to closely and critically examine how the documentarians narrativize Smith's mistreatment and the discourses that they draw upon to do so. While The Fifth Estate decries CSC's failure to provide Smith with appropriate care, they do so in a way that largely conceptualizes mental illness as an individual pathology, which obscures how structural barriers, conditions of confinement, and institutional power relations create emotional distress (Kilty 2006, 167; 2012, 165-66; Pollack 2006, 240) and how punishment, notably the use of segregation, is gendered (Pollack and Kendall 2005, 85). We suggest that some of the ways that The Fifth Estate references Smith's gender contribute to sensationalizing the case by upholding representations of hegemonic femininity and the notion that women who "misbehave" must be "fixed" (Dell, Fillmore, and Kilty 2009, 288). By offering a critical feminist critique of The Fifth Estate documentaries, this paper draws attention to how mainstream media coverage-even that which was directly critical of CSC's practices-eclipsed considering structural factors in favour of discourses that individualize and pathologize Smith's behaviour ${ }^{2}$. Especially in light of their failure to adequately recognize how carceral practices produce material experiences of emotional distress and suffering, we problematize, question the value of, and largely oppose dominant correctional and psychiatric pathologization discourses.

Some scholars suggest that media outlets can help to hold criminal justice institutions accountable by shining a spotlight on injustice (Cooke and Sturges 2009, 421; Culhane 1991, 32; Geraghty and Velez 2011, 480, 484)-a "watchdog" role that The Fifth Estate certainly exudes. We contribute to this conversation by providing a specific example of how media representations may reveal and condemn particular institutional practices while simultaneously reproducing the discourses upon which those practices rest. Our purpose is not simply to point out what The Fifth Estate documentaries leave out; like other stories and interpretations, including the one we provide, documentaries have angles that require highlighting and excluding various avenues of inquiry. Instead, we argue that the particular angle taken up in the documentaries and the specific discourses they marginalize align with pathologizing and individualizing discourses that underpin and legitimize the very correctional system that they critique. In this sense, it is not that The Fifth Estate prioritized a mental health angle in their storytelling that is problematic, but rather that they primarily frame the issue as an exposé of how carceral institutions that should provide psychiatric care fail to do so because of a lack of adequate resources and accountability. As a result, the documentaries do not question the practice of incarceration or the correctional representation of unruly women as psychologically maladjusted.

2 In critiquing the documentaries, we do not suggest that The Fifth Estate deliberately upheld individualizing or pathologizing discourses. Instead, we agree with Jewkes $(2015,46)$ who eschews notions of journalistic conspiracy and points out that journalists may "shar[e] the same ideological values as the majority of their audiences" (emphasis in original). It is not our aim to speculate on what the documentarians' intentions may or may not have been, but rather to trace the discourses they mobilize as they create narratives that they think will "matter to Canadians" (CBC's The Fifth Estate website). 
Revealing the results of a detailed narrative analysis of "Out of Control" (OC) (2010) and "Behind the Wall" (BW) (2010), we juxtapose the narratives about the Smith case produced by The Fifth Estate against the claims made by feminist criminologists with respect to women's corrections. In particular, we argue that The Fifth Estate documentaries align with neoliberal and post-feminist notions of individualism and gender neutrality that obscure the structural context in which prisoner mistreatment takes place. To do so, we begin by outlining key feminist critiques of women's corrections and discussing how these claims may be countered and undermined by neoliberal and post-feminist individualism. Introducing the concept of "through narrative," we then provide a methodological discussion of how each documentary uses monologues, interview clips, and video evidence to weave together a coherent narrative about the case. Next, we consider how these coherent narratives uphold dominant medicalized conceptualizations of mental illness and mental health treatment. Finally, we discuss The Fifth Estate's reliance upon gendered stereotypes and its failure to consider how Smith's status as a "misbehaving" woman prisoner contributed to her brutal treatment. While The Fifth Estate undoubtedly critiques CSC's practices and the egregious mistreatment of prisoners, they do so in a way that fails to challenge the gendered nature of prison practices that reinforce Smith's pathologization.

\section{Feminist Critique in the Age of "Equality"}

Far from being a unitary body of scholarship, feminist criminologies engage a multitude of theoretical perspectives and substantive areas (Comack 2006, 32-44; Moore 2008, 48; Snider 2003, 361). For example, feminist criminologists have problematized male-centred correctional approaches and research, asserted the particularities of women's experiences in prison, privileged women's experiential knowledge, examined the diverse power relations in the criminal justice system, and interrogated dominant truth claims about women's involvement in crime (Comack 2006, 32-44; Moore 2008, 50-55). Furthermore, ongoing disagreements permeate feminist scholarship, as exemplified by debates about whether poststructuralism's movement away from notions of patriarchy and centralized state power might undercut political action (Moore 2008, 55; Smart 1994, 21-25) and in the tensions between feminist efforts to reform women's prisons and feminist critiques of reform (Snider 2003, 371-2).

We draw upon the work of feminist criminologists who critique issues relevant to the Smith case, namely the gendered nature of punitive carceral practices (e.g., segregation, strip-searching) and the mobilization of mental health discourses that pathologize criminalized women. In particular, we consider the following problems: the use of psychiatry and psychology to "tame" and control women prisoners (Pollack and Kendall 2005, 83; Kilty 2012, 178); the gendered expectations that serve to justify the extra-punitive treatment of criminalized women (Dell, Fillmore, and Kilty 2009, 288; Hannah-Moffat 2001, 177); and the use of segregation for self-injuring women and those deemed mentally ill (Dell, Fillmore, and Kilty 2009, 297; Kilty 2006, 167; Martel 2006, 592). These concerns feature as the primary focal points in our juxtaposition of The Fifth Estate narratives against feminist critiques. 
Within correctional discourse, women's offending is often individualized ${ }^{3}$ as either "the outcome of poor choices" (Hannah-Moffat 2005, 41) or the result of a psychologically damaged mind (Pollack 2006, 239; Rose 1996, 101-15), both of which obscure the social, cultural, political, and economic contexts of criminalization. Individual women prisoners are seen as in need of being "fixed," often through therapeutic approaches that encourage them to internalize the notion that they have an inherently "criminal personality" (Pollack 2006, 243), "low self-esteem" (Cruikshank 1999, 58-66, 87-103) or "something wrong on the inside" (McCorkel 2003, 70). As a result, social factors such as gender and racial discrimination, poverty and other forms of marginalization are affixed to individual women as mental health needs that constitute them as "risky" subjects (Pollack and Kendall 2005, 83; Snider 2006, 330).

Criminalized women who, like Smith, engage in self-harming behaviour or are deemed violent are constituted as "unfeminine, 'misbehaved' women" who are especially deserving of punitive treatment because they break both the law and traditional gender roles (Dell, Fillmore, and Kilty 2009, 288). In order to be seen as "recovering," women prisoners are expected to adhere to a gendered script of passivity, dependency, and non-violence (Dell, Fillmore, and Kilty 2009, 291). Those women who refuse or fail to comply with correctional interventions and gendered scripts of recovery are seen as "difficult to manage," "dangerous," and even "unempowerable" (Hannah-Moffat 2001, 177)_discursive framings that CSC embraces to justify the use of punitive restraints and practices in the name of maintaining institutional security. Chief among these practices is segregation, despite research that identifies its "emotionally devastating consequences" (Arrigo and Bullock 2008, 636). For instance, Martel $(2006,608)$ found that the loss of spatio-temporal referencing that is encountered in segregation causes women to have difficulty perceiving themselves as "being" in the world. Kilty $(2006,174)$ argues that segregating women who self-injure demonstrates how institutional security is valued above their personal safety and security.

Although these feminist critiques shed light on the gendered nature of incarceration and help explain why Smith, as a "misbehaving" and "difficult" female prisoner, was subjected to punitive treatment, they must be considered within the context of a purportedly "post-feminist era" (Chunn 2007, 51), wherein the feminist movement is often seen as no longer necessary, feminism is reduced to notions of individual choice and self-empowerment, and critiques of structural inequality gain less traction (Anderson 2014, 19-20). Emphasizing the "superficial empowerment of the individual and her choices" (Anderson 2014, 19), post-feminist rationality intertwines with neoliberalism ${ }^{4}$, which upholds ideals of free and fair competition, formal equality, individual responsibility, and self-determination

Of course, the individualization of behaviour is not specific to women; neoliberal rationalities reduce social conditions to individual qualities and choices for men as well.

4 Although we focus our analysis on particular dimensions of neoliberal rationality, it is important to recognize that different political rationalities co-exist, as O'Malley $(1999,185-89)$ demonstrates in his discussion of how the "New Right" simultaneously relies on ideals from neoconservativism and neoliberalism. Amable (2011, 21-26) also explains that neoliberalism did not 'replace' or 'debunk' welfarism, and there are ways that these two rationalities converge. 
(Amable 2011, 15, 24-5). Within this context, efforts to "level the playing field" and notions of "equality of opportunity" act as substitutes for substantive equality (Amable 2011, 24-5), reframing and justifying social inequalities by attributing them to "irresponsible," "failed" subjects. Neoliberal and post-feminist privileging of the (genderless) individual rational actor undermines the very grounds on which feminists and other equality-seeking groups stake their claims. In effect, neoliberalism limits the discursive space in which issues of substantive inequality between different social groups can legitimately be raised, replacing it with a discourse that erodes the relevance of gender by "constructing both men and women as genderless individuals and, optimally, as self-sufficient market actors in pursuit of self-interest, freedom, and choice" (Brodie 2008a, 170). In this context, formal equality is valued over substantive equality and women's self-empowerment and freedom of choice is seen as synonymous with gender equality.

Despite feminist claims about the persistence of substantive gender inequality in Canadian society (Brodie 2008b, 147) and gendered oppression in Canadian prisons (Dell, Fillmore, and Kilty 2009, 290), notions of achieved formal equality that reduce equality to "gender neutrality" and "identical treatment" abound (Chunn 2007, 42). Moreover, the post-feminist idea that "we are all equal now" (Brodie 2008b, 160) portrays feminists and other equality seeking groups as "selfinterested lobby group [s]" (Brodie 1995, 69) that work against the needs of "ordinary" Canadians (Chunn 2007, 52; Sawer 2006, 122). At the same time, there are anti-feminist sentiments that regard feminists as threats to men's rights, health and safety (Menzies 2007, 83-85) such that, for some, feminism may constitute "the new ' $F$ ' word" (Brodie 1995, 67). As a comparative example of how social justice movements can be reframed as somehow working against "equal" treatment, the growing Black Lives Matter movement, which seeks to draw attention to the systemic devaluing of Black lives, has been perceived by some as an exclusionary affront to other racial and social groups, such as white citizens and police officers. Asserting that "all lives matter," those challenging the Black Lives Matter movement have mobilized the language of "sameness" and "identical treatment" to perpetuate the problematic invisibility of white privilege. Discourses that reduce equality to superficial notions of "neutral treatment" obscure the reality of systemic privilege, undermine calls for structural and substantive change to ameliorate the material experiences of disadvantaged groups, and reframe equality seeking groups as unfairly and selfishly privileging the needs of a special interest group over the interests of "all lives."

While the substantial defunding of women's organizations over the past decade (Johnson 2015, 405) makes anti-feminist sentiments seem particularly acute, it is important to keep in mind that these challenges are neither new, nor are they allencompassing and uniform (Chunn, Boyd and Lessard 2007, 10). In fact, recent political and cultural occurrences demonstrate the complexity of how feminism is at once applauded and contested. For example, in 2015, Canadian Prime Minister Justin Trudeau introduced the first gender-balanced cabinet and along with notable celebrities like Beyoncé and Emma Watson, proudly declares himself a feminist. A resurgence of feminist organizing was also witnessed globally in early 2017 by protest demonstrations and marches in response to the inauguration of US President 
Donald Trump. Despite recent public celebrations of feminism ${ }^{5}$, post-feminist sentiments that proclaim the feminist accomplishment of gender equality and question why women should receive "special treatment" persist. In the context of women's experiences in the penal and correctional systems, where feminist efforts to highlight the particularities of women's material needs are often reconstituted through the therapeutic language of self-transformation and self-esteem building (Cruikshank 1999, 58-66, 87-103) and are sometimes met with hostile claims that women are treated with leniency in comparison to men (Snider 2003, 363-64), it is particularly important to interrogate media constructions of criminalized women as emotionally or mentally unstable.

Despite critiquing CSC's ability to provide adequate mental health treatment, The Fifth Estate relies upon correctional discourses that situate Smith's continued selfinjurious behaviour as a key indicator of her mental illness, lack of self-esteem, and inability to self-govern (Cruikshank 1999, 58-66, 87-103), which systematically decontextualizes her resistant actions and by extension, those taken up by other women in prison. The Fifth Estate's coverage of the Smith case thus offers a poignant opportunity to examine how mainstream media may perpetuate post-feminist and neoliberal notions of individual responsibility and achieved gender equality, obscuring the structural factors that underpin and reproduce gendered punishment. In the next section, we provide a methodological discussion of our approach to narrative analysis and describe how the two Fifth Estate episodes discursively constructed a coherent and relatable narrative about the Smith case that, while critical of correctional practices, effectively upholds gendered constructions of the pathological criminal woman.

\section{Weaving a Coherent Narrative}

Documentary films require an internal organizing logic that often takes a narrative form (Nichols 2010, 21). Not only does a narrative organize the documentary by providing a coherent storyline, it also advances and "supports an underlying proposal, assertion, or claim about the historical world" (Nichols 2010, 23). Although narratives are often presented as though they are simply uncovered through investigation, they are constructed or imposed because "real events do not offer themselves as stories" (White 1987, 4). Recounting events in narrative form necessarily involves a process of selection, whereby certain events, details, and pieces of information are included, organized, and interpreted in a particular way, while other events or details are excluded (Riessman and Quinney 2005, 394; White 1987, 10). Imposing a narrative structure upon real events imbues them with significance, moral meaning, and a degree of closure (White 1987, 24).

In The Fifth Estate documentaries, the Smith case is organized, evaluated, and infused with particular meanings by what we term a "through narrative." We conceptualize the through narrative as a figurative thread and needle that punctures each interview segment, narrator monologue, and video surveillance clip, drawing out and focusing on certain aspects or issues among many in order to connect each particular scene to the overall storyline and themes being explored. While each scene may include

While there has been a recent resurgence in the women's movement and feminist self-identification, the documentaries predate this renewal (both airing in 2010). 
different details or claims, documentarians edit, frame, and position it within the documentary to give it meaning that advances the through narrative. This necessarily leaves unexplored many comments, issues, or details that are mentioned but not drawn out as significant to the through narrative. For instance, The Fifth Estate host Hana Gartner mentions that Smith was initially sentenced to the New Brunswick Youth Centre, which was "a two-hour drive from home" (OC), but fails to provide any further commentary on the harms associated with geographic dislocation for prisoners. Instead, the through narrative in "Out of Control" focuses almost exclusively on whether the detention centre was safe and therapeutic. The way the through narrative threads across the scenes upholds particular conclusions and arguments about the case and creates a narrative coherence that gives The Fifth Estate's account the appearance of fullness despite the issues, content, and interpretations that were excluded or marginalized.

In our analysis, we drew upon the work of socio-linguist William Labov, specifically his work on narrative structure. Defining narrative as "a particular way of retelling past events” (2013, 15), Labov (1972, 363-66; 2013, 27-32) suggests that many narratives contain some or all of the following elements: the abstract, which summarizes the story and indicates what it is about; the orientation, which describes the setting; the complicating action, which relates the temporally ordered chain of events (i.e. "what happened"); the result, which indicates the outcome of the action; the evaluation, which provides commentary and attributes meaning to aspects of the narrative; and the coda, which ends the narrative by commenting on how things are now. While the abstract is usually offered at the beginning of the narrative and the coda at the end, these narrative elements can be dispersed at various points throughout a narrative. Using Labov's model, our analysis involved: a detailed examination ${ }^{6}$ of each scene, including the arguments made, the scene's setting, the way questions were posed/answered, language used, and visual content; consideration of each documentary's overall narrative structure by analysing each scene's narrative function (i.e. abstract, orientation, action, result, evaluation, or coda) relative to the rest of the documentary; and juxtaposition of the overall arguments made in the documentaries against the aforementioned feminist claims regarding women's corrections.

With respect to narrative structure, we found that each documentary begins with a two- to three-minute abstract, followed by several scenes of orientation, and then is primarily organized around a back and forth sequence between the complicating action and evaluation elements. In particular, the following pattern emerges in each "through narrative": description of a complicating action (e.g., Smith being sent to the Regional Psychiatric Centre in Saskatoon) $\rightarrow$ several evaluation scenes ${ }^{7}$ commenting on that action (e.g., an interview clip with Smith's mother; a monologue by the narrator, Hana Gartner) $\rightarrow$ a description of the next complicating action (which is framed within the previous actions and evaluations) $\rightarrow$ several evaluation scenes. Although they both follow this action/evaluation pattern, the documentaries are organized in slightly different ways. Notably, "Out of Control" often presents evaluative scenes that conflict with one another, whereas "Behind the Wall" primarily offers evaluative scenes that support and complement one another.

To facilitate analysis, both documentaries were transcribed verbatim.

Evaluations are typically provided through either interview clips or comments by the narrator. 
For instance, "Out of Control" recounts the complicating action of Smith being sent to the New Brunswick Youth Centre (NBYC), then offers the following evaluations: the NBYC "describe[s] itself as a safe and secure environment for youth," while an interview clip shows Bernard Richard ${ }^{8}$ describing it as "a very hard reality." Since the documentarians cannot create a coherent "through narrative" while simultaneously advancing opposing arguments, the evaluation conflict must be resolved. This is done by presenting them in a way that undermines or discredits one evaluation and supports the other. In the previous example, the documentary resolves the conflicting evaluations by revealing that the NBYC's description as a "safe and secure environment" is "double speak" (Richard) to try to soften the institution's image. Supported evaluations frame and contextualize subsequent actions and connect with the key themes and arguments of the through narrative. Figure 1 provides a visual representation of this pattern.

\begin{tabular}{|c|c|}
\hline \multicolumn{2}{|c|}{$\begin{array}{l}\text { Complicating Action } \\
\text { (a particular incident, detail, or event in the story is described) } \\
\text { e.g., Smith held in segregation for the entire time she was in the federal correctional system }\end{array}$} \\
\hline $\begin{array}{l}\text { Evaluation } \\
\text { (initial commentary on the action) } \\
\text { e.g., "segregation isn't punitive" (Dan } \\
\text { Erickson, CSC representative) }\end{array}$ & $\begin{array}{c}\text { Evaluation } \\
\text { (conflicting commentary on the action) } \\
\text { e.g., segregation is unsafe and inhumane } \\
\text { (Kim Pate }{ }^{9} \text { and Federal Correctional } \\
\text { Investigator Howard Sapers) }\end{array}$ \\
\hline $\begin{array}{r}\text { Framing the C } \\
\text { (the documentary supports one evalu } \\
\text { simultaneously advancing opposing ar } \\
\text { e.g., narration by Gartner frames Erickson } \\
\text { Fifth Estate's interview with the warden an } \\
\text { about Ashley Smith"; the first evaluation } \\
\text { dismissed as institutional cover-up and the } \\
\text { is presen }\end{array}$ & $\begin{array}{l}\text { ting Evaluations } \\
\text { and discredits conflicting evaluations; } \\
\text { ts would produce internal incoherence) } \\
\text { ement by recounting how CSC cancelled The } \\
\text { Erickson "on the condition [they] do not ask } \\
\text { gregation isn't punitive) is thus framed and } \\
\text { d (i.e., segregation as unsafe and inhumane) } \\
\text { leoitimate }\end{array}$ \\
\hline $\begin{array}{l}\text { Compl } \\
\text { (the next incident is then } \mathrm{fr} \\
\text { e.g., the supported argument that segre } \\
\text { complicating action-Smi }\end{array}$ & $\begin{array}{l}\text { Action } \\
\text { oy the supported evaluation) } \\
\text { is unsafe and inhumane frames the next } \\
\text { ng out while in segregation }\end{array}$ \\
\hline
\end{tabular}

Figure $1 \mathrm{CSC}=$ Correctional Service of Canada

Conflicting evaluations help create the impression that the conclusions drawn were "found" by weighing the evidence of competing interpretations. By including evaluations that conflict (often through interview clips with

8 Richard was the New Brunswick Ombudsman and investigated Smith's treatment at the NBYC.

9 Kim Pate was the Executive Director of the Canadian Association of Elizabeth Fry Societies, a network advocating for women in prison. 
different informants) and then framing one as more legitimate, the supported evaluation becomes part of the "through narrative" while conflicting evaluations are dismissed. Organizing the documentary around conflicting evaluations is thus a powerful technique for creating a credible and seemingly self-evident narrative argument.

Advancing its through narrative in a slightly different manner, "Behind the Wall" primarily presents complementary evaluations ${ }^{10}$ and constructs a surrounding narrative that frames and corroborates the documentary's main narrative. Rather than offering conflicting evaluations, "Behind the Wall" primarily relies on evaluations that build upon one another to advance a key point about a particular action that supports the through narrative. For example, interview clips with Julian Falconer, the Smith family's lawyer, and Howard Sapers corroborate and complement one another to emphasize the illegality and inhumanity of CSC's use of segregation. Furthermore, "Behind the Wall" contains two intertwined plotlines: the main narrative, which recounts what happened "behind the wall," and the surrounding narrative, which tells a story about The Fifth Estate's investigation. The main narrative describes CSC's use and coverup of abusive prison practices; its complicating actions include events such as Smith's overall mistreatment (e.g., illegal institutional transfers, permanent isolation, multiple uses of force against her), the comparative example of fellow prisoner Justine Winder's ${ }^{11}$ restraint on a Pinel board, and the effects of an unwritten correctional code of silence. The surrounding narrative recounts the difficulty that the documentarians experienced when seeking answers about Canadian prisons; it consists of events such as The Fifth Estate investigators being prevented from accessing the Regional Psychiatric Centre and CSC Nurse Cindy stating over the phone that she is too afraid to do an on-camera interview.

While the main narrative is the focus of the documentary, the surrounding narrative corroborates and illustrates aspects of the main narrative. For example, assertions that CSC's lack of transparency facilitates the continuation of abusive practices are corroborated by an event in the surrounding narrative: after attempting to contact prison staff, Gartner receives a phone call from a CSC communications officer who indicates that she should speak to a CSC spokesperson. As in this example, most of the complicating actions in the surrounding narrative are shown as they happen (e.g., footage of Gartner being denied entry to the Regional Psychiatric Centre), which emphasizes CSC's cover-up efforts and the obstacles The Fifth Estate encountered while conducting their investigation. Figure 2 illustrates how complementary evaluations and these intertwining narratives are used to advance the "through narrative" in "Behind the Wall."

10 We use the term 'complementary evaluations' to refer to evaluations that interpret the action from a similar angle and position.

11 Justine Winder is referred to as "another inmate in crisis" (Gartner). She was incarcerated after "a fight with her boyfriend turned ugly" (Gartner) and like Smith, she began to self-injure while in federal custody. 


\begin{tabular}{|c|c|c|c|c|}
\hline \multicolumn{4}{|c|}{$\begin{array}{l}\text { Complicating Action (Main Narrative) } \\
\text { e.g., John Torella }{ }^{12} \text { dismissed for assaulting Smith } \rightarrow \\
\text { guards rally around Torella (threats and violence } \\
\text { towards witnesses) } \rightarrow \text { Torella acquitted }\end{array}$} & $\begin{array}{l}\text { Complicating Action } \\
\text { (Surrounding Narrative) } \\
\text { e.g., CSC Nurse } e^{13} \text { afraid to be } \\
\text { interviewed by The Fifth Estate }\end{array}$ \\
\hline $\begin{array}{c}\text { Evaluation } \\
\text { e.g., violence } \\
\text { against witnesses } \\
\text { as a national } \\
\text { problem }\end{array}$ & $\begin{array}{c}\text { Evaluation } \\
\text { e.g., Torella's } \\
\text { lawyer claims } \\
\text { that he did what } \\
\text { he had to do }\end{array}$ & \multicolumn{2}{|c|}{$\begin{array}{l}\text { Evaluation } \\
\text { e.g., people afraid } \\
\text { to be witnesses } \\
\text { against the abuse }\end{array}$} & $\begin{array}{c}\text { Evaluation } \\
\text { e.g., speaking out about abuses is }\end{array}$ \\
\hline \multicolumn{4}{|c|}{$\begin{array}{l}\text { The evaluations build upon one another. } \\
\text { e.g., guards across the country are being acquitted of } \\
\text { violence against prisoners by silencing witnesses and } \\
\text { arguing in court that they "did what they had to do" }\end{array}$} & $\begin{array}{l}\text { The surrounding narrative shows } \\
\text { the Fifth Estate's struggles to } \\
\text { document what is happening in }\end{array}$ \\
\hline \multicolumn{5}{|c|}{$\begin{array}{l}\text { The action of the surrounding narrative tends to corroborate the key arguments of the main } \\
\text { narrative; these arguments then frame subsequent actions. } \\
\text { e.g., the nurse's fear of being interviewed corroborates the assertion that CSC officials are } \\
\text { hiding prisoner abuse by threatening witnesses. }\end{array}$} \\
\hline \multicolumn{5}{|c|}{ Complicating Action (Main Narrative) } \\
\hline \multicolumn{3}{|c|}{$\begin{array}{l}\text { Evaluation } \\
\text { a is emotionally damaging }\end{array}$} & \multicolumn{2}{|c|}{$\begin{array}{c}\text { Evaluation } \\
\text { e.g., segregation and transfers are illegal }\end{array}$} \\
\hline \multicolumn{5}{|c|}{$\begin{array}{l}\text { The evaluations complement each other and are framed by previous actions and evaluations. } \\
\text { e.g., the practices to which Smith was subjected, such as isolation, are not only hidden, but } \\
\text { also harmful and illegal }\end{array}$} \\
\hline
\end{tabular}

Figure $2 \mathrm{CSC}=$ Correctional Service of Canada

The differences in how the two documentary narratives are constructed likely stems from the fact that "Behind the Wall," the second documentary, is built on the conclusions drawn in "Out of Control." Organized around complicating actions and conflicting evaluations, the "through narrative" in "Out of Control" constructs Smith as "a troubled young girl who cried out for help and never got it" (Gartner) and builds toward the following conclusions: "they [CSC] took her life" (Coralee Smith ${ }^{14}$ ); CSC poses a threat to youth with mental illness; and the public is largely unaware of this threat and should be informed. Since "Behind the Wall" is a follow-up episode on the case, there was no need to reiterate conflicting evaluations that were previously resolved, such as whether or not the treatment Smith received was punitive.

12 John Torella was a CSC supervisor who was charged with assaulting Smith while she was choking herself.

13 Cindy was the nurse on duty when Smith was assaulted by Torella; she initially filed a false report and then three days later came forward to report Torella's actions.

14 Coralee Smith is Ashley's mother; she adopted Ashley when she was five days old. 
Instead, "Behind the Wall" begins from the position that it was and that Smith's life was taken by asking "Who did that to Ashley?" (Coralee Smith). Through complementary evaluations and intertwined main/surrounding narratives, "Behind the Wall" expands on the pre-established argument that CSC poses a threat to prisoners suffering from mental illness. Building on the "through narrative" presented in "Out of Control," it advances the following conclusions: CSC and the correctional workers involved "let her die" (Gartner); federal prisons are concealing the ways in which abusive practices are used against mentally ill prisoners like Smith; and what happened to Smith could happen to "anybody's child" (Coralee Smith).

Although they do so in slightly different ways, both documentaries gradually walk viewers through Ashley Smith's story, advancing arguments and producing an internally coherent "through narrative" via description and evaluation of certain incidents and practices. By drawing out and emphasizing certain issues at the expense of others, the documentaries also marginalize and exclude issues or points of discussion that could have been raised to interpret and attribute meaning to the story. As White (1987, 24) argues, the coherence and clarity produced in a narrative "is and only can be imaginary." Real events do not present themselves in the structured coherence of a narrative and consequently any attempt to present them as such involves a process of selecting, deleting, emphasizing, marginalizing, and tilting various details, events, and evaluations (Riessman and Quinney 2005, 394; White 1987, 4). The "through narratives" in "Out of Control" and "Behind the Wall" represent many different decisions about how to frame and present the Smith case. In the next two sections, we argue that the through narratives draw upon psy discourses (Rose 1996, 101-15) that pathologize prisoner behaviour, obscure structural oppressions and institutional power relations, and fail to consider the gendered nature of carceral practices.

\section{Framing the Smith Case: Mentally Ill Prisoners and the Lack of Care Inside}

As stated on the CBC website, The Fifth Estate is concerned with providing "in-depth investigations that matter to Canadians." In keeping with this focus, both documentaries feature interview clips emphasizing that "Canada should know" (Coralee Smith, OC) and that "every Canadian ... has a vested interest in knowing what goes on inside a place like this [prison or psychiatric centre]" (Don Davies ${ }^{15}$, $\mathrm{BW}$ ). The Smith case is used as a foundation for discussing broader issues, namely, "how kids with mental health and behavioural problems are treated behind bars in this country" (Gartner, OC) and "how Canadian prisons punish the mentally ill" (Gartner, BW). By making these claims, The Fifth Estate echoes the critiques offered by feminist criminologists and scholars in the "mad movement" who argue that correctional responses to those experiencing mental distress are often punitive in nature (e.g., Arrigo and Bullock 2008, 632; Dej 2016, 125; Kilty 2012, 165; Menzies, LeFrançois, and Reaume 2013, 2, 10; Pollack 2006, 241). At the same time, however, the documentaries rely on a narrative of mental illness that aligns with neoliberal notions of individualism and the need to "fix" misbehaving individuals who transgress cultural (and gendered) behavioural expectations.

15 Don Davies is an NDP Member of Parliament and was "vice-chair of a Parliamentary Committee studying mental health care in [Canadian] penitentiaries" (Gartner, BW). 
Critiquing CSC's treatment of Smith and prisoners "like her," "Out of Control" highlights how "isolating inmates with mental disorders is unsafe and inhumane" (Gartner). The Smith case is described as "a classic model of the failure of our ... corrections system to adequately care for the mentally ill in society" (Peter van Loan $^{16}$ ) and it is revealed that there are "young people in jail for minor infractions, for mental ... conditions not being treated" (Coralee Smith). Similarly, "Behind the Wall" focuses on "the shocking truth" that "Canadian prisons punish the mentally ill" (Gartner). Both documentaries emphasize how the abuse of mentally ill prisoners is not limited to the one case; Smith's story of "cr[ying] out for help and never g[etting] it ... is not unique" (Gartner, OC).

In "Behind the Wall," interviewees discuss how there are "many cases of physical and more perhaps emotional, psychological abuses" (Atkinson ${ }^{17}$ ) in which patients "are being punished for being mentally ill" (Gartner). This point is corroborated by: CSC nurse Bonnie Bracken's ${ }^{18}$ discussion of "a male patient that was a lot like Ashley" whom she witnessed being beaten; by the discussion of Justine Winder, who was physically restrained in the same manner as Smith; and by Davies's reference to an incarcerated woman he saw who was restrained for three months. These testimonies highlight that CSC punished Smith "instead of treating her" (Gartner, BW) and that this is a common occurrence. Failure to provide mental health care is presented as a standard problem across prisons and existing punitive practices (e.g., the use of Taser guns, pepper spray, segregation, and restraints) are identified as harmful to an especially vulnerable population. Furthermore, The Fifth Estate identifies several systemic problems in CSC's mental health care: CSC “ignores its own rules and breaks the law" (Gartner, BW), "spends less than two percent of its [operating budget] on mental health care for inmates" (Gartner, BW), and only provides correctional workers with a "two-hour online mental health course" (Gartner, BW).

As these quotes demonstrate, The Fifth Estate's coverage of the Smith case offers a valuable critique of mental health care in Canadian prisons. Highlighting the lack of mental health care in both the community and the carceral setting, the documentaries show how the prison system has become "a de facto mental health facility" (Richard, OC) - one in which workers are "assessing, diagnosing, and prescribing medication [but] they're not doing any counselling whatsoever" (Davies, BW). This reflects scholars' efforts to critique the use of isolation in response to mental health distress and the prison's failure to provide adequate care (Arrigo and Bullock 2008, 625-26, 632; Haney 2008, 964-65, 973; Kilty 2012, 168, 172-77). Moreover, The Fifth Estate depicts Smith as "caught in the divide between security and treatment" (Gartner, BW). Kilty $(2012,174,178)$ similarly critiques the correctional prioritization of institutional security, arguing that it undermines therapeutic practices and reduces psy treatment primarily to the administration of psychotropic medication. In this way, The Fifth Estate documentaries identify key

16 Peter van Loan is a Conservative Member of Parliament and was the Minister for Public Safety, a position that includes the responsibility of overseeing Canada's federal prison system.

17 Linda Atkinson is a social worker who previously worked as a guard.

18 Bracken was a nurse for twenty-five years at the Regional Psychiatric Centre and interacted with Smith on many occasions. 
problems in how prisons respond to mental health issues. Through interviews with key informants and surveillance video footage of Smith's mistreatment, The Fifth Estate offers an emotional critique of abusive prison practices and demands "significant improvements" (Gartner, OC) in correctional mental health care.

That said, The Fifth Estate relies on a medical model interpretation of mental illness that pathologizes emotional distress and obscures the socio-economic and structural factors, such as sexism, racism, and poverty, that are linked to criminalization and imprisonment (Pollack 2000, 81; 2006, 239; Pollack and Kendall 2005, 73). Notable feminist criminologists and "mad" scholars contend that medicalized approaches to care are often degrading for those who are diagnosed or constructed as mentally ill and problematically reduce a host of multifarious historical, social, and institutional factors to questions of how individual inadequacies might be managed (Dej 2016, 125; Menzies, LeFrançois, and Reaume 2013, 2, 10; Pollack $2006,241)$. By presenting the Smith case primarily as an issue of inadequately treated mental illness, not only do the documentaries uphold the notion that "the problem and the solution to the problem, lie within the individual woman herself" (Pollack 2000, 79), they also fail to problematize the incarceration of mentally ill people, instead suggesting that it is the lack of resources that is at issue.

Repeatedly emphasizing Smith's need for psychiatric care, the documentaries advance the idea that prisoners "like Smith" are "transformative risk subject[s]" that are "amenable to targeted therapeutic interventions" (Hannah-Moffat 2005, 31). Smith is characterized as one of the "kids with mental health and behavioural problems ... behind bars" (Gartner, OC) and her "out of control" behaviour is framed as stemming from CSC's failure to provide psychiatric assessment and treatment. Gartner makes a series of statements to this effect: Smith "never had a comprehensive mental health assessment" (OC); "no one knew how to handle Ashley because no one knew what was wrong with her" (OC); "she was never fully assessed or meaningfully treated" (OC); "there was nothing in the guards' two-hour online mental health course that prepared them for Ashley Smith" (BW); "instead of treating her, they punished Ashley's behaviour with pepper spray and restraints" (BW).

As discussed above, these comments critique CSC's failure to provide mental health care in a way that assumes Smith had something inherently "wrong" with her prior to incarceration. Indicating that Smith's story begins "not as you might predict, but in a nice neat home with parents who really care" (Gartner, OC), The Fifth Estate reveals that "the trouble started" when "Ashley began to change" from "a sweet, playful girl" to a teenager demonstrating "defiant, disrespectful, and disruptive" (Gartner, OC) behaviour. Immediately after recounting this change, The Fifth Estate shows that Smith's parents attempted to have her diagnosed but "there had been no real follow-up" (Gartner, OC). While we do not wish to dismiss the possibility that Smith may have benefited from psychological care or that she was experiencing emotional distress, The Fifth Estate's presentation of "when the trouble started" presents psychological maladjustment as the only explanation for Smith's initial (and continued) disruptive behaviour. The documentaries repeatedly show that, instead of treating her, "prison made Ashley worse" (Gartner, OC), which underscores that Smith had pre-existing mental and emotional problems that were aggravated by her experiences inside. 
In emphasizing the lack of mental health care, the documentaries leave unquestioned what constitutes helpful therapeutic treatment. In "Behind the Wall," for example, Gartner describes the Regional Psychiatric Centre in Saskatoon as "the only psychiatric hospital in the country with a therapeutic healing program designed for women offenders" although it has "only twelve beds for women." These comments suggest that the main problem is that prisons do not provide enough treatment to women, the solution to which is to provide more of the same therapeutic approaches that feminists have long identified as problematic. For example, correctional therapies for women have been found to be wrought with coercion (Kilty 2012, 168; Pollack 2006, 239, 244), to problematically encourage women to see themselves as having a "criminal personality" (Pollack 2006, 243), and to engage treatment techniques such as distress tolerance, which emphasizes skilfully coping with pain and "encourage[s] women to accept and internalize their oppression” (Pollack and Kendall 2005, 79). These approaches primarily serve the purpose of "taming' women whose unruly emotions may interfere with the smooth operation of the prison" (Pollack 2006, 245) and have the potential to undermine women's resistance to abusive prison practices, such as segregation, physical and psychotropic restraints, and strip-searching.

The notion of mental illness is used in The Fifth Estate documentaries much like a "public image," which Hall et al. $(1978,118)$ describe as "a cluster of impressions, themes and quasi-explanations gathered or fused together" that are drawn from dominant ideologies and "stop short of serious, searching analysis." When used to explain an event or phenomenon, public images keep the discussion within "the boundaries of a dominant ideological field" and any analysis offered "seems to collapse into the image" (Hall et al. 1978, 118). Critiques of Smith's mistreatment continually return to an image of mental illness that aligns with neoliberal individualism and the pathologization of mental distress and resistant behaviour. Stopping short of questions about what constitutes mental illness, The Fifth Estate works from the presumption that Smith's behaviour was indicative of a mental disorder. In this way, the critique offered in the documentaries collapses into an image of untreated mental illness: significant changes need to be made in prisons so that prisoners suffering from mental distress can be assessed and treated without excessive isolation and uses of force. Although the notions of vulnerability and a desperate need for help that are associated with this image of mental illness allow The Fifth Estate to create an emotionally charged discussion of Smith that condemns CSC's actions, reliance on this public image also focuses on the individual as the site for therapeutic interventions and obscures some of the structural, and perhaps more controversial, problems revealed by this case. In the next section we examine this exclusion more closely by considering how the "through narratives" in the two Fifth Estate episodes fail to consider the way that Smith's mistreatment was structured by gendered expectations and practices.

\section{Avoiding the "F-word": The Missed Opportunity to Provide a Gendered Analysis}

As White $(1987,10)$ explains, “Every narrative, however seemingly 'full', is constructed on the basis of a set of events that might have been included but were left 
out." Not only is content inevitably left out during the process of compiling, editing, and producing the documentaries, there are also issues raised and statements made within each documentary that could have been presented as significant but were instead left unexplored. The Fifth Estate uses the themes of mental illness and lack of mental health care to explain the events of the case and to draw connections across various scenes, thereby generating a coherent "through narrative" organized around a main issue. In so doing, however, they downplay the importance of other issues that are only briefly mentioned, such as the geographic dislocation Smith experienced during her incarceration or the repeated strip-searching to which she was subject. Like the documentarians, we also provide a particular "through narrative" to highlight how The Fifth Estate reinforces pathologizing discourses and overlooks the gendered practices that contributed to Smith's mistreatment; as such, ours is not the only story that could be told about the documentaries. For instance, the extensive media coverage surrounding the Smith case, juxtaposed against the negligent attention given to the death of Edward Snowshoe, an Indigenous man who similarly died in a segregation cell in 2010, demonstrates the white privilege that shapes whose experiences "matter to Canadians" (CBC's The Fifth Estate website $\left.^{19}\right)$. The Fifth Estate portrays Smith as representative of "what's happening to our young people" (Coralee Smith, OC), "to kids with mental health and behavioural problems" (Gartner, OC) and to "the mentally ill" (Gartner, BW). In this way, the imprisonment and mistreatment of a young, white woman is presented as an issue that should matter to viewers because she could have been "anybody's child" (Coralee Smith, OC). At the same time, the racialized experiences of prisoners such as Edward Snowshoe remain unconsidered. While this paper focuses on gender and The Fifth Estate's representation of femininity, the media attention following the Smith case also points to the ways that racialization shapes "newsworthiness" (Jewkes 2015, 45).

Although The Fifth Estate mentions Smith's gender and shows interview clips with Kim Pate ${ }^{20}$, the Executive Director of "a national organization advocating for women in prison" (Gartner, OC), no critique is offered of the ways that gender shaped correctional interpretations of, and responses to, Smith's behaviour. Instead, we found that the episodes draw upon certain essentialized stereotypes of femininity and girlhood that further sensationalize the case. For example, at the beginning of "Out of Control" Smith is described as "a troubled young girl who cried out for help and never got it" (Gartner) and an interview with Coralee Smith showing Ashley's "girly" doll collection narrates her as having been a "sweet, playful girl" (Gartner). These references to gender present Smith as initially adhering to standard tropes of hegemonic femininity, which Schippers $(2007,94)$ describes as "the characteristics defined as womanly that ... guarantee the dominant position of men and the

$19 \mathrm{http} / / /$ www.cbc.ca/fifth/about/.

20 Although the inclusion of interview clips with Kim Pate might suggest the presence of a gendered analysis, The Fifth Estate uses the clips primarily to reveal the conditions of Smith's confinement and to show CSC's lack of mental health care. They are edited to highlight what Pate saw as "one of the few visitors Ashley was allowed" (Gartner) and to show that "when [she] last saw Ashley [she] asked a number of people to intervene right up to the regional and national level and ... nobody did" (Pate). 
subordination of women," including physical vulnerability, passivity, domesticity, and compliance. After presenting Smith as adhering to feminine stereotypes as a child (e.g., "sweet" and "girly"), Gartner states that there is "not one clue [in her home environment] as to how everything went so terribly wrong." Inherent in these comments is the implication that if Smith had been violent or unfeminine as a child, rather than "sweet," "playful," and "girly," it would have helped explain why things "went wrong" - and would have perhaps made the case less shocking.

Although introduced in "Out of Control" as a "young girl" and a "girly" child, Smith is primarily identified in both documentaries as one of the "kids with mental health and behavioural problems" (Gartner, OC) and an example of "how Canadian prisons punish the mentally ill" (Gartner, BW). In fact, as we mentioned in the previous section, mental illness is presented as the reason Smith changed from a "sweet, playful girl" to being "on the verge of being out of control” (Coralee Smith, OC). After describing Smith's normative girlhood, The Fifth Estate suggests that "Ashley began to change" (Gartner, OC) when she was around thirteen or fourteen (e.g., breaking rules; getting expelled from school) and that the psychological help her parents sought was insufficient.

The documentaries overlook questions of gendered punishment and craft a "through narrative" around the public image of mental illness despite the fact that the policies and practices in women's corrections are "inherently gendered and punitive in nature" and rely upon "traditional patriarchal conceptions of femininity" (Dell, Fillmore, and Kilty 2009, 286). Correctional discourse juxtaposes the "unfeminine misbehaved woman prisoner" (Dell, Fillmore, and Kilty 2009, 288) against stereotypes of hegemonic femininity in order to justify the use of force against women seen as "misbehaving." Several feminist scholars identify segregation as a common correctional response to women who are deemed "difficult to manage"-often due to self-injurious behaviour or presumed mental illness (Kilty 2006, 167; Martel 2006, 592). Although The Fifth Estate mentions Smith's "reputation for being the most difficult female inmate in the system" (Gartner, BW), there is no consideration of how being seen as a "difficult" and "misbehaved" female prisoner may have impacted her behaviour and treatment. By constructing a through narrative that portrays CSC's treatment of Smith as a series of inhumane responses to mental illness, the documentaries obscure the gendered aspects of carceral control practices, like the fact that women are more likely to be sentenced to time in segregation for less serious institutional infractions and self-injury than are men (Office of the Correctional Investigator 2015).

This failure to consider gender is somewhat surprising given that The Fifth Estate broke the 1994 story of women at the Prison for Women in Kingston (P4W) being forcibly removed from their segregation cells and illegally strip-searched by a male institutional emergency response team. The Fifth Estate's coverage of this event garnered the attention of both the Canadian public and policy makers, triggering a federally commissioned public inquiry (Arbour 1996) that condemned the conditions of women's corrections. Despite the parallels between the correctional responses to Smith and the women in P4W, The Fifth Estate does not mention its coverage of the 1994 cell extractions, missing the opportunity to demonstrate the historical continuity of women's carceral mistreatment. 
In fact, women's corrections is characterized as a place where Smith could and should have been treated. In "Out of Control," the Grand Valley Institution for Women is described as having been "built with female inmates in mind, ha[ving] a more home-y look and offer[ing] a mental health program tailored especially to women" (Gartner). Gartner then states that Grand Valley provides "the kind of help Ashley could have used, but the warden locked her in segregation the minute she got $[t]$ here." As aforementioned, in "Behind the Wall," the Regional Psychiatric Centre in Saskatoon is problematized for having "over 200 patients, but only 12 beds for women offenders" (Gartner). Although Smith was sent to the Regional Psychiatric Centre to "get a diagnosis and a treatment plan" (Gartner), the documentary recounts how this did not occur because she was subject to constant isolation. These comments characterize mental health programs "tailored especially to women" as inherently positive and suggest that the failure occurred in denying Smith access to them. In this way, prison is problematized only in so far as it does not provide enough treatment for mentally ill prisoners and "women-centred" corrections is problematically presented as creating a "home-y" environment.

The discussion of Justine Winder in "Behind the Wall" further exemplifies The Fifth Estate's problematic failure to consider feminist claims regarding women's experiences of imprisonment. When it is revealed that Winder began self-injuring in prison, she is described as being "like so many women offenders [in that] [she] turned her anger inward [and] she started cutting her arms and choking herself" (Gartner). While this discussion suggests that the prison was "transforming her" (Gartner), and by extension other women prisoners, there is no critical discussion of women's self-injury in prison or penal responses to it. On the contrary, Winder's inwardly turned anger is presented as the reason she self-injures "like so many women offenders" (Gartner), which attributes women's self-injury in prison to an irrational misdirection of anger and reflects CSC reports that claim women selfinjure "as a means of coping with negative emotions" (Power and Usher 2010, 28). While these "negative emotions" may result from incarceration, CSC research and The Fifth Estate documentaries are both devoid of any discussion of women's selfinjury as a meaningful response to isolation and mistreatment, relying instead on pathologizing discourses that attribute the behaviour to emotional and psychological maladjustment. This ignores feminist arguments that view self-injury as a response to the powerlessness created by oppressive prison environments and suggest that self-injury "may represent an attempt to resist the power of the prison and to demonstrate personal agency" (Kilty 2006, 165; see also Pollack and Kendall 2005, 76; Robert, Frigon, and Belzile 2007, 184).

The Fifth Estate uses Smith's gender and youth to heighten the "newsworthiness" (Jewkes 2015,45 ) of the case, suggesting that the story is particularly shocking because Smith was a "troubled young girl" (Gartner, OC) who was "sweet" and "playful" prior to her incarceration. At the same time, the documentaries do not question the gendered implications of the different carceral practices (e.g., stripsearching, medicalization, and forced psychotropics) used to contain Smith, instead advancing "through narratives" organized around the theme of mental illness. In so doing, the documentaries uphold stereotypical images of femininity and reproduce correctional discourses that pathologize criminalized women. While The Fifth Estate 
reveals serious problems in correctional mental health care, it also relies upon neoliberal and post-feminist notions of individualism that primarily root Smith's selfinjurious and resistant behaviours in her flawed psyche rather than her conditions of confinement and the chronic abusive prison practices to which she was subject. In this way, the Smith case is not used to elucidate women's mistreatment in the federal correctional system, but to discuss how "mentally ill inmates" (Gartner, BW) are mistreated and denied psychiatric care, which problematically reinforces a veneer of gender equality or neutrality regarding Canadian prison practices.

\section{Conclusion}

Using a novel approach to documentary analysis drawn from narrative inquiry and socio-linguistics that contributes to the methodological advancement of the disciplines of criminology and media studies, we hope this research will push criminologists to adopt more innovative analytic practices. By critically examining The Fifth Estate's narration of the Ashley Smith case, we explored how mainstream media coverage that is expressly critical of CSC may nonetheless reproduce some of the assumptions and modes of thought upon which correctional practices rest. In particular, the documentaries uphold correctional discourses that locate criminality and resistant behaviour within the disordered minds and thinking patterns of individual women. Both episodes construct "through narratives" that position Smith as mentally ill and the lack of therapeutic resources in prison as the underlying systemic failure that led to her death. While The Fifth Estate condemns CSC's treatment of Smith and prisoners like her, their adoption of the medical model interpretation of mental illness engages neoliberal notions of individualism, leaving intact and reproducing pathologizing discourses that continue to underpin women's corrections. Even as they reveal and critique the "shocking truth" (Gartner, BW) and indisputable mistreatment of mentally ill prisoners, The Fifth Estate draws upon some of the same discourses that sustain and justify the correctional system they critique.

Failing to consider Smith's "out of control" behaviour as a rational or meaningful response to her powerlessness and experiences of being segregated, stripsearched, and restrained, The Fifth Estate highlights that "prison made Ashley worse" (Gartner, OC), thus presuming that she was inherently disordered to begin with. Moreover, the episodes do not question what constitutes treatment in women's corrections and thus ignore feminist concerns about coercive therapeutic practices that can encourage women to accept oppressive conditions and internalize negative characterizations of the self (Pollack and Kendall 2005, 79). In fact, The Fifth Estate uncritically accepts women-centred mental health programming as "the kind of help Ashley could have used" (Gartner, OC), suggesting that more treatment would improve corrections. This brings to mind Foucault's $(1981,155)$ claim that "a transformation that remains within the same mode of thought ... can merely be a superficial transformation." By working from the presumption that prisoners like Smith have something wrong with them that can be fixed through better access to (augmented) mental health programming, The Fifth Estate suggests improvements that would leave structural oppressions untouched, which ultimately legitimizes incarceration and some of the problematic carceral practices to which Smith was subjected. 
Eclipsed by the focus on mental illness are questions of how Smith's status as a difficult and misbehaving woman prisoner impacted her punishment. Interest-oriented media processes tend to go hand in hand with content and as The Fifth Estate aims to reach a broad national audience, taking up the critical language and vocabulary of feminism and a direct analysis of the gendered nature of punishment might risk alienating potential viewers that either deny the continued need for feminism or who openly reject that identity. Instead, The Fifth Estate frames the case within the confines of individualism and thus in a way that maintains the status quo and may resonate with a wider audience. In so doing, however, they overlook the gendered aspects of correctional punishment and instead reproduce post-feminist and neoliberal discourses that emphasize the need for "self-transformation rather than structural transformation" (Anderson 2014, 10, original emphasis).

\section{References}

Amable, Bruno. 2011. Morals and politics in the ideology of neo-liberalism. Socio-Economic Review 9: 3-30.

Anderson, Kristin J. 2014. Modern Misogyny: Anti-Feminism in a Post-Feminist Era. New York: Oxford University Press.

Arbour, Louise. 1996. Commission of Inquiry into Certain Events at the Prison for Women in Kingston (Canada). Ottawa: Public Works and Government Services, Canada.

Arrigo, Bruce A., and Jennifer L. Bullock. 2008. The psychological effects of solitary confinement on prisoners in Supermax Units. International Journal of Offender Therapy and Comparative Criminology 52 (6): 622-40.

Brodie, Janine. 1995. Politics on the Margins: Restructuring and the Canadian Women's Movement. Nova Scotia: Fernwood Publishing.

Brodie, Janine M. 2008a. Putting gender back in: Women and social policy reform in Canada. In Gendering the Nation State: Canadian and Comparative Perspectives, ed. Yasmeen Abu-Laban (Vancouver: UBC Press), 165-84.

Brodie, Janine. 2008b. We are all equal now: Contemporary gender politics in Canada. Feminist Theory 9 (2): 145-64.

The Fifth Estate. November 2010. Behind the Wall. Marie Caloz (Producer/Director); Hana Gartner (Writer). CBC. http://www.cbc.ca/fifth/episodes/2010-2011/behind-the-wall.

The Fifth Estate. January 2010. Out of Control. Marie Caloz (Producer/Director); Hana Gartner (Writer). CBC. http://www.cbc.ca/fifth/episodes/2009-2010/out-of-control.

The Fifth Estate. April 2015. Secrets of the Fifth Estate. CBC. http://www.cbc.ca/fifth/ episodes/2014-2015/secrets-of-the-fifth-estate.

Chunn, Dorothy E. 2007. "Take it easy girls": Feminism, equality, and social change in the media. In Reaction and Resistance: Feminism, Law and Social Change, ed. Dorothy E. Chunn, Susan B. Boyd, and Hester Lessard (British Columbia: UBC Press), 32-64.

Chunn, Dorothy E., Susan B. Boyd, and Hester Lessard. 2007. Feminism, law, and social change: An overview. In Reaction and Resistance: Feminism, Law and Social Change, ed. Dorothy E. Chunn, Susan B. Boyd, and Hester Lessard (British Columbia: UBC Press), $1-28$.

Comack, Elizabeth. 2006. The feminist engagement with criminology. In Criminalizing Women: Gender and (In)justice in Neo-liberal Times, ed. Gillian Balfour and Elizabeth Comack (Nova Scotia: Fernwood), 22-55.

Cooke, Louise, and Paul Sturges. 2009. Police and media relations in an era of freedom of information. Policing \& Society 19 (4): 406-24. 
Cruikshank, Barbara. 1999. The Will to Empower. Ithaca NY: Cornell University Press.

Culhane, Claire. 1991. No Longer Barred from Prison: Social Injustice in Canada. Montréal: Black Rose Books.

Dej, Erin. 2016. Psychocentrism and homelessness: The pathologization/responsibilization paradox. Studies in Social Justice 10 (1): 117-35.

Dell, Colleen A., Catherine J. Fillmore, and Jennifer M. Kilty. 2009. Looking back 10 years after the Arbour inquiry: Ideology, policy, practice, and the federal female prisoner. The Prison Journal 89 (3): 286-308.

Foucault, Michel. 1981. Practicing criticism. In Politics, Philosophy, Culture: Interviews and Other Writings, 1977-1984, ed. Lawrence D. Kritzman. New York: Routledge.

Geraghty, Sarah, and Melanie Velez. 2011. Bringing transparency and accountability to criminal justice institutions in the South. Stanford Law \& Policy Review 22 (2): 455-88.

Hall, Stuart M., Chas Critcher, Tony Jefferson, John Clarke, and Brian Roberts. 1978. Policing the Crisis: Mugging, the State and Law \& Order. New York: Palgrave Macmillan.

Haney, Craig. 2008. A culture of harm: Taming the dynamics of cruelty in Supermax prisons. Criminal Justice and Behavior 35 (8): 956-84.

Hannah-Moffat, Kelly. 2001. Punishment in Disguise: Penal Governance and Federal Imprisonment of Women in Canada. Toronto: University of Toronto Press.

-2005. Criminogenic needs and the transformative risk subject: Hybridizations of risk/need in penality. Punishment \& Society 7 (1): 29-51.

Jewkes, Yvonne. 2015. Media \& Crime, $3^{\text {rd }}$ ed. London: Sage.

Johnson, Holly. 2015. Degendering violence. Social Politics: International Studies in Gender, State and Society 22 (3): 390-410.

Kilty, Jennifer M. 2006. Under the barred umbrella: Is there room for a women-centered self-injury policy in Canadian corrections? Criminology \& Public Policy 5 (1): 161-82.

—. 2012. "It's like they don't want you to get better": Psy control of women in the carceral context. Feminism \& Psychology 22 (2): 162-82.

Labov, William. 1972. The transformation of experience in narrative syntax. In Language in the Inner City, 354-396. Philadelphia: University of Pennsylvania Press.

- 2013. Narrative analysis. In The Language of Life and Death: The Transformation of Experience in Oral Narrative, 14-43. Cambridge: Cambridge University Press.

Martel, Joane. 2006. To be, one has to be somewhere: Spatio-temporality in prison segregation. British Journal of Criminology 46 (4): 587-612.

McCorkel, Jill A. 2003. Embodied surveillance and the gendering of punishment. Journal of Contemporary Ethnography 32 (1): 41-76.

Menzies, Robert J. 2007. Virtual backlash: Representations of men's "rights" and feminist "wrongs" in cyberspace. In Reaction and Resistance: Feminism, Law and Social Change, ed. Dorothy E. Chunn, Susan B. Boyd, and Hester Lessard, 65-97. British Columbia: UBC Press.

Menzies, Robert, Brenda A. LeFrançois, and Geoffrey Reaume. 2013. Introducing mad studies. In Mad Matters: A Critical Reader in Canadian Mad Studies, ed. Brenda A. LeFrançois, Robert Menzies, and Geoffrey Reaume, 1-22. Toronto: Canadian Scholars' Press.

Moore, Dawn. 2008. Feminist criminology: Gain, loss and backlash. Sociology Compass 2 (1): $48-61$.

Nichols, Bill. 2010. Introduction to Documentary. $2^{\text {nd }}$ ed. Bloomington, Indiana: Indiana University Press.

Office of the Correctional Investigator. 2015. Administrative Segregation in Federal Corrections: 10 Year Trends. Ottawa, Ontario: Office of the Correctional Investigator. http://www. oci-bec.gc.ca/cnt/rpt/oth-aut/oth-aut20150528-eng.aspx.

O’Malley, Pat. 1999. Volatile and contradictory punishment. Theoretical Criminology 3 (2): 175-96. 
Pollack, Shoshana. 2000. Reconceptualizing women's agency and empowerment: Challenges to self-esteem discourse and women's lawbreaking. Women and Criminal Justice 12 (1): $75-89$.

-2006. Therapeutic programming as a regulatory practice in women's prisons. In Criminalizing Women: Gender and (In)justice in Neo-liberal Times, ed. Gillian Balfour and Elizabeth Comack, 236-249. Nova Scotia: Fernwood.

Pollack, Shoshana, and Kathy Kendall. 2005. Taming the shrew: Regulating prisoners through women-centered mental health programming. Critical Criminology 13: 71-87.

Power, Jenelle, and Amelia Usher. 2010. A Qualitative Study of Self-Injurious Behaviour in Women Offenders (Summary). Research Report R-225. Ottawa, Ontario: Correctional Service of Canada. http://www.csc-scc.gc.ca/research/005008-0225-01-eng.shtml.

Riessman, Catherine K., and Lee Quinney. 2005. Narrative in social work: A critical review. Qualitative Social Work 4 (4): 391-412.

Robert, Dominique, Sylvie Frigon, and Renée Belzile. 2007. Women, the embodiment of health, and carceral space. International Journal of Prisoner Health 3 (3): 176-88.

Rose, Nikolas S. 1996. Inventing Our Selves: Psychology, Power, and Personhood. Cambridge and New York: Cambridge University Press.

Sawer, Marian. 2006. From women's interests to special interests: Reframing equality claims. In The Politics of Women's Interests: New Comparative Perspectives, ed. Louise Chappell and Lisa Hill, 111-29. Abingdon, Oxfordshire: Routledge.

Schippers, Mimi. 2007. Recovering the feminine other: Masculinity, femininity, and gender hegemony. Theory and Society 36 (1): 85-102.

Smart, Carol. 1994. Law, feminism and sexuality: From essence to ethics? Canadian Journal of Law and Society 9 (1): 15-38.

Snider, Laureen. 2003. Constituting the punishable woman: Atavistic man incarcerates postmodern woman. British Journal of Criminology 43 (2): 354-78.

-2006. Making change in neo-liberal times. In Criminalizing Women: Gender and (In)justice in Neo-liberal Times, ed. Gillian Balfour and Elizabeth Comack, 323-342. Nova Scotia: Fernwood.

White, Hayden V. 1987. The value of narrativity in the representation of reality. In The Content of the Form: Narrative Discourse and Historical Representation, 1-25. Baltimore, Maryland: Johns Hopkins University Press.

Charissa Crépault

Doctoral Candidate

Department of Criminology

University of Ottawa

cweir029@uottawa.ca

Jennifer M. Kilty

Associate Professor

Department of Criminology

University of Ottawa

jkilty@uottawa.ca 